\title{
Neonatal alloimmun trombocytopenisk purpura (NAITP)
}

\author{
Bjørn Skogen \\ Avdeling for immunologi og transfusjonsmedisin, Regionsykehuset i Tromsø, 9038 Tromsø \\ Telefon: 77626295 Telefax: 77626304 E-mail: ILABBS@RITO.NO
}

\begin{abstract}
SAMMENDRAG
Neonatal alloimmun trombocytopenisk purpura (NAITP) opptrer før eller like etter fødselen, og er forårsaket av maternell alloimmunisering mot paternelle (føtale) antigener som ikke er tilstede på morens trombocytter. Incidensen er 1 pr. 2000/3000 nyfødte. Det finnes ikke noe screening-opplegg for å avsløre mødre som kommer til å føde barn med NAITP. Derfor fins det heller ikke noe man kan gjøre før en kvinne føder sitt første barn med tilstanden. I påfølgende svangerskap kan moren følges, og man kan planlegge tiltak for å redusere risikoen for skade på barnet.
\end{abstract}

Skogen B. Neonatal alloimmune thrombocytopenic purpura. Nor J Epidemiol 1997; 7 (1): 69-72.

\section{ENGLISH SUMMARY}

Neonatal alloimmune thrombocytopenic purpura (NAITP) manifests itself before or shortly after birth and is caused by maternal alloimmunization to a paternal (fetal) antigen not present on the mother's platelets. The incidence of the condition in the fetus and neonate is 1 in 2000/3000 live births. There are no screening programs for detecting mothers at risk of delivering infants affected with NAITP. Therefore, no antenatal management is possible in first pregnancies. In subsequent pregnancies there is an opportunity to detect affected fetuses and plan perinatal therapy.

\section{INTRODUKSJON}

Blødningstendens som følge av trombocytopeni er en meget alvorlig klinisk tilstand. En betydelig andel av trombocytopeniene har immunologisk årsak. Ved idiopatisk trombocytopenisk purpura (ITP) kan man finne autoantistoffer mot pasientens egne trombocytter. Alloantistoffer kan være årsak til trombocytopeni hos pasienter med post transfusjons purpura og hos multitransfunderte pasienter som ikke får noen stigning $\mathrm{i}$ trombocyttall etter trombocyttransfusjoner. Medikamenter kan fungere som haptener, eller indusere neoantigener, som gir opphav til antistoffdannelse og trombocytopeni. Alloantistoffer mot trombocyttspesifikke antigener kan være årsak til trombocytopeni hos fostere og nyfødte som har fått overført antistoffene fra sin mor. Hos barn som får symptomer er platetallet vanligvis lavere enn $30 \times 10^{9} / \mathrm{L}$ (1). $10-20 \%$ av trombocytopeniene hos nyfødte skyldes antistoffer, og det er som regel de mest alvorlige tilfellene $(2,3)$.

\section{INCIDENS}

NAITP opptrer med en incidens på 1 pr. 2000-3000 fødsler (4). Hvis vi går ut fra at det er ca. 60000 fødsler pr. år i Norge, betyr det at mellom 20 og 30 tilfeller av NAITP opptrer hvert år. Som nevnt er anti-HPA 1a det antistoffet som oftest gir alvorlig trombocytopeni hos foster/nyfødte. Ettersom frekvensen av HPA $1 \mathrm{bb}$ er $2 \%$, betyr det at bare en liten del av de 1200 uforlikelige svangerskapene pr. år kompliseres med alvorlig føtal trombocytopeni. Det er rapportert at 6,5-14\% av NAITP tilfellene får dramatisk utgang, med fosterdød som resultat, det vil si 2-4 barn årlig (4-6). Intrakranial blødning og/eller varige skader forekommer i 15-28 prosent av tilfellene (5-10 barn årlig) (6-8). Opptil halvparten av tilfellene med intrakraniale blødninger opptrer før fødsel, og kan inntreffe så tidlig som i 13. svangerskapsuke $(9,10)$.

\section{Patogenese}

NAITP er en analog til hemolytisk sykdom hos nyfødte (11). Dersom et foster arver et trombocyttantigen som faren har, men som moren mangler, kan hun bli immunisert med dette antigenet. Immuniseringen kan skje allerede i første trimester av svangerskapet, derfor affiseres et uforlikelig foster som regel i første svangerskap ved denne tilstanden. Dette er anderledes enn ved hemolytisk sykdom hos nyfødte, hvor immuniseringen som regel foregår i forbindelse med fødsel, og sykdom opptrer i påfølgende svangerskap. Antistoffer av IgG klasse kan passere placenta og føre til trombocytopeni hos fosteret. Fosteret kan bli utsatt for 
alvorlige blødninger, med intrakranial blødning og/eller fosterdød som de mest dramatiske følgene. Alloantistoffene ved NAITP gir oftere alvorlig trombocytopeni hos fosteret enn autoantistoffene som finnes hos mødre med ITP. Det er derfor av stor betydning å skille mellom trombocyttantistoffer av alloimmun og autoimmun genese.

Kvinner med genotype HPA 1 bb som har vært gravide eller transfunderte, er mest utsatt for post transfusjons purpura. Dersom en kvinne som er HPA 1bb, har fătt påvist anti-HPA 1a, bør hun fortrinnsvis transfunderes med komponenter fra givere som er HPA $1 \mathrm{bb}$.

\section{ANDRE ÅRSAKER TIL NEONATAL TROMBOCYTOPENI}

Hos opptil $80 \%$ av pasientene med ITP, kan det påvises antistoffer på egne trombocytter, det vil si autoantistoff mot trombocytter.

Fosteret hos en kvinne med idiopatisk (autoimmun) trombocytopeni og frie trombocyttantistoffer av IgG klasse i serum, kan bli utsatt for immunbetinget trombocytopeni (11). Trombocytopenien hos fosteret er som regel mindre uttalt, og den kliniske tilstanden mindre alvorlig enn ved NAITP. Det er derfor viktig å kunne skille mellom allo- og autoantistoff mot trombocytter hos gravide.

En gravid kvinne med trombocytopeni skal utredes med tanke på trombocytt-autoantistoffer for eventuelt å bekrefte en autoimmun trombocytopeni (ATP). Dersom kvinnen har antistoffer på egne trombocytter, bør hun følges opp i svangerskapet, spesielt hvis hun tidligere har født et barn med trombocytopeni.

Bakterielle eller virale infeksjoner, disseminert intravaskulær koagulasjon, og medikamentbruk hos moren kan føre til trombocytopeni hos en nyfødt. Mer sjeldne årsaker er hemangiom/trombocytopeni syndrom, kongenital amegakaryocytisk hypoplasi, trombocytopeni ved manglende radius (TAR) syndrom, kongenital levkemi, histiocytose og Wiscott-Aldrich syndrom.

\section{Plateantigenene}

Både blodgruppeantigener (ABH) og vevstypeantigener (HLA) av klasse I er til stede på trombocyttoverflaten og kan være mål for antistoffer som kan redusere overlevelsestiden for trombocyttene i sirkulasjonen. Ved neonatal alloimmun trombocytopeni finner man antistoffer mot trombocyttspesifikke alloantigener. Tabell I viser endel karakteristika for de mest vanlige trombocytt-spesifikke antigenene (12).

Ved neonatal alloimmun trombocytopeni finner man oftest antistoff mot HPA 1a, som er et antigen lokalisert til glycoprotein IIIa. Dette antistoffet finnes i $80-90 \%$ av tilfellene med NAITP (11). Hos omtrent alle kvinnene som danner a-HPA 1a antistoff med klinisk konsekvens for fosteret, finnes vevstypeantigenet HLA-DRw52a (13). Antistoff mot HPA 1b har også vært observert. Ellers har antistoffer mot antigener i alle de nevnte systemene vært implisert. Det har ennå ikke vært klart påvist at vevstypeantistoffer spiller en rolle ved NAITP, men ved noen tilfeller av neonatal trombocytopeni hvor man ikke har funnet annen årsak, har det vært påvist sterke vevstypeantistoffer. Man tror derfor at også vevstypeantistoffer kan føre til NAITP i enkelte tilfeller $(11,14)$.

\section{DIAGNOSTIKK}

Det har i flere år vært mulig å utrede neonatal trombocytopeni med tanke på trombocyttantistoffer som årsak, og servicen har vært tilgjengelig her i landet (15). Mulighetene til å utføre slik diagnostikk har blitt betydelig forbedret med innføring av molekylærbiologisk teknologi i trombocytt-alloantigentypingen, og bedre spesifisitetsbestemmelse av antistoffene med spesiell immunoenzymatisk metode (16). Komplett utredning av NAITP tilbys nå av Avdeling for immunologi og transfusjonsmedisin ved Regionsykehuset i Tromsø, som har Landsfunksjon for trombocyttimmunologiske spissfunksjoner. Påvisning av trombocyttantistoffer utføres ved flere regionsykehus (blodbanker).

Tabell I. De mest vanlige trombocytt-spesifikke alloantigen systemene.

\begin{tabular}{|c|c|c|c|c|c|}
\hline $\begin{array}{c}\text { Alloantigen } \\
\text { system }\end{array}$ & $\begin{array}{c}\text { Glykoprotein } \\
\text { lokalisasjon }\end{array}$ & $\begin{array}{c}\text { Aminosyre } \\
\text { posisjon }\end{array}$ & Aminosyre & $\begin{array}{c}\text { DNA } \\
\text { codon }\end{array}$ & $\begin{array}{c}\text { Fenotypefrekvens, } \\
\text { kaukasiere }\end{array}$ \\
\hline HPA 1a & IIIa & 33 & Leu & CTG & $98 \%$ \\
HPA 1b & IIIa & 33 & Pro & CCG & $28 \%$ \\
\hline HPA 2a & Ib & 145 & Met & ATG & $99 \%$ \\
HPA 2b & Ib & 145 & Thr & ACG & $15 \%$ \\
\hline HPA 3a & IIb & 843 & Ile & ATC & $85 \%$ \\
HPA 3b & IIb & 843 & Ser & AGC & $63 \%$ \\
\hline HPA 4a & IIIa & 143 & Arg & CGA & $99 \%$ \\
HPA 4b & IIIa & 143 & Gln & CAA & $<0,1 \%$ \\
\hline HPA 5a & Ia & 505 & Lys & AAG & $99 \%$ \\
HPA 5b & Ia & 505 & Glu & GAG & $20 \%$ \\
\hline HPA 6a & IIIa & 489 & Arg & CGG/CGA/CGC & $99 \%$ \\
HPA 6b & IIIa & 489 & Gln & CAG & $<0,1 \%$ \\
\hline
\end{tabular}


Tilstanden er sannsynligvis underdiagnostisert i Norge idag. Ut fra den prøvemengden vi idag mottar, er det vanskelig å tro at alle tilfellene med neonatal trombocytopeni utredes komplett. Det er derfor ikke mulig å påvise alle tilfellene av NAITP. Derfor er det heller ikke mulig å si om situasjonen i Norge er sammenlignbar med andre land. I 1996 utredet vi 30 tilfeller med neonatal trombocytopeni, og 10 av disse hadde NAITP. Beregnet av statistikk fra andre land, skulle vi forvente mellom $20 \mathrm{og} 30$ tilfeller.

Tilstanden skulle være godt kjent i aktuelle fagmiljøer $(15,16)$. I forbindelse med etableringen av den nasjonale servicefunksjonen på dette området, vil vi imidlertid i nærmeste fremtid sende en orientering om det diagnostiske tilbudet vårt til alle landets sykehus.

Selv om sjansene for NAITP øker med antall svangerskap, er prognosene for de neste svangerskapene bedre enn for det første. Dette skyldes sannsynligvis de tiltakene som kan settes inn i forbindelse med de neste svangerskapene, som sectio eller blodplatetransfusjoner. I dag gjøres ingen tiltak for å påvise NAITP i første svangerskap. NAITP kan diagnostiseres med relativ stor grad av sikkerhet dersom det startes utredning i familier der barn får påvist petecchier, blødningstendens og trombocytopeni i neonatalperioden.

Det finnes i dag muligheter for intrauterin diagnostikk og behandling av fosteret, og det er derfor lett å erkjenne betydningen av riktig diagnostikk av trombocytopeni hos nyfødte $(2,17,18)$.

Dersom det ikke er andre åpenbare årsaker til trombocytopeni hos et nyfødt barn, skal det utredes med tanke på NAITP. Også ved dødfødsler og gjentatte aborter bør man tenke på NAITP.

Det er vanlig å gjøre trombocytt allo- og autoantistoffundersøkelse hos mor. Farens trombocytter inkluderes $\mathrm{i}$ testen for å oppdage eventuell uforlikelighet for sjeldne alloantigener. Det skal også gjøres en antistoff spesifisitetsbestemmelse hos mor samt trombocyttalloantigen typing av mor, far og barn. Forutsetningen for å stille diagnosen NAITP, er at det i tillegg til trombocytopeni hos barnet, påvises uforlikelighet mellom mor og far i et av trombocytt-alloantigensystemene, at mor har antistoff mot det aktuelle antigenet, og at barnet har arvet dette antigenet fra faren.

\section{ANALYSER}

Trombocyttantistoffer påvises i en indirekte immunfluorescensteknikk med trombocytter i suspensjon, og fluorescens påvises med flowcytometrisk teknikk. På denne måten får man en semikvantitativ bestemmelse av antistoffene (19).

Spesifisitetsbestemmelse av trombocyttantistoffer gjøres i en ELISA test. Testen er laget slik at man kan bestemme hvilke glykoproteiner på trombocyttoverflaten antistoffene er rettet mot. Ved å velge typede test-trombocytter med kjente overflateantigener, kan man definere antistoffenes spesifisitet (20).

Tidligere ble trombocyttenes fenotype bestemt serologisk. På grunn av mangel på velkarakteriserte, monospesifikke antisera for mange av allotypene, er det nå mer vanlig å gjøre genotyping basert på PCR (polymerase kjede reaksjon). PCR kan kombineres med både dot-blot hybridiserings teknikk, spalting med restriksjonsenzymer eller utføres med sekvensspesifikke primere. Den sistnevnte varianten er enkel, rask og pålitelig (12).

\section{OPPFØLGING OG BEHANDLING}

En kvinne som har født et barn med NAITP må følges nøye i neste svangerskap. Intensiteten i oppfølgingen avgjøres av alvorlighetsgraden av det første observerte tilfellet med NAITP. Hvis et barn får diagnostisert NAITP, er det mer enn $95 \%$ sjanse for at neste barn er affisert $(7,11)$. Kunnskap om fars genetiske konstitusjon (homozygot/heterozygot) er viktig for oppfølgingen i det neste svangerskapet. Dersom far er homozygot, vil fosteret arve det antigenet som mor har antistoff mot. Dersom far er heterozygot, er det 50\% sjanse for at fosteret ikke arver det antigenet og vil da være utenfor risiko.

Spesifisitetsbestemmelse av antistoffet er viktig. Trombocytt autoantistoff hos moren (ITP) og antiHLA antistoffer (som er relativt hyppig hos kvinner som har vært gravide) gir vanligvis ikke alvorlig trombocytopeni hos fosteret.

Hvis den kliniske tilstanden til det første trombocytopeniske barnet tilsier det, og faren er heterozygot, må man vurdere å gjøre diagnostikk på fosteret. Dette kan gjøres med perkutan umbilikal blodprøvetaking (PUBS). Ved slik prosedyre må man ha forlikelige trombocytter tilgjengelig for transfusjon. Ved noen sentra transfunderer man alltid ved slik prøvetaking.

Affiserte fostre med svært lave trombocyttall kan behandles med intrauterine transfusjoner med forlikelige trombocytter. Slike transfusjoner må foretas ukentlig frem til forløsning (14).

Noen steder utføres PUBS ved ca. 36 ukers graviditet. Dersom trombocyttallet er lavere enn $50 \times 10^{9} / \mathrm{L}$, er det ikke uvanlig å anbefale sectio (11). Man gir da en trombocyttransfusjon like før sectio forløsning for å beskytte barnet i perinatalperioden.

Ettersom de fleste sykehus vil ha problemer med å skaffe forlikelige trombocytter fra andre givere, er det nærliggende å bruke moren som trombocyttgiver. Plasmaet må da fjernes fra trombocyttene med en vaskeprosedyre før transfusjon, for ikke å tilføre barnet ytterligere antistoffer. Noen vil foretrekke å gi forlikelige trombocytter fra andre givere, for å slippe å belaste moren ekstra med trombocyttaferese i en ellers vanskelig situasjon. Man trenger da heller ikke å vaske trombocyttene.

Det er rapportert varierende effekt på fosterets trombocyttall når moren behandles med intravenøs gammaglobulin. I stedet for trombocyttransfusjon har det også vært forsøkt med intravenøs gammaglobulin til barnet like etter fødselen. Dette har i mange tilfeller hatt god effekt på trombocyttnivået. 


\section{REFERANSER}

1. Aster RH, George JN. Thrombocytopenia due to enhanced platelet destruction by immunologic mechanisms, in: Williams WJ, Beutler E, Erslev AJ, Lichtman MA (Eds.): Hematology. McGraw-Hill Publishing Company 1990: 1370-1398.

2. Reznikoff-Etievant MF. Management of alloimmune neonatal and antenatal thrombocytopenia. Vox Sang 1988; 55: 193-201.

3. Mueller-Eckhardt C, Kiefel V, Grubert A, Kroll H, Weisheit M, Schmidt S, Mueller-Eckhardt G, Santoso S. 348 cases of suspected neonatal alloimmune thrombocytopenia. Lancet 1989; i: 363-366.

4. Deaver JE, Leppert PC, Zaroulis CG. Neonatal alloimmune thrombocytopenic purpura. Am J Perinatol 1986; 3: $127-131$.

5. Pearson HA, Shulman NR, Marder VJ, Cone TE Jr. Isoimmune neonatal thrombocytopenic purpura: Clinical and therapeutic considerations. Blood 1964; 23: 154-177.

6. Kaplan C, Daffos S, Forestier F, Morel MC, Chesnel N, Tchernia G. Current trends in neonatal alloimmune thrombocytopenia: Diagnosis and therapy. In: Kaplan-Gouet C, Schlegel N, Salmon C, McGregor J (Eds.): Platelet immunology: Fundamental and clinical aspects. Paris, Colloque INSERM Vol. 206/John Libbey Eurotext, 1991: 267-278.

7. Shulman NR, Jordan JV. Platelet immunology. In: Coleman RW, Hirsh J, Marder JV, Salzman EW (Eds.): Hemostasis and thrombosis. Philadelphia: JB Lippincott 1987; 452-529.

8. Mueller-Eckhardt C, Mueller-Eckhardt G, Willen-Ohff $\mathrm{H}$ et al. Immunogenicity of and immune response to the human platelet antigen Zwa is strongly associated with HLA-B8 and DR3. Tissue Antigens 1985; 26: 71-76.

9. Waters A, Murphy M, Hambley H, Nicolaides K. Management of alloimmune thrombocytopenia in the fetus and neonate. In: Nance SJ (Ed.): Clinical and basic science aspects of immunohematology. Arlington, AABB 1991: 155-177.

10. Neonatal immune thrombocytopenia working party. Neonatal alloimmune thrombocytopenia (NAIT): Information derived from a prospective international registry (abstract). Pediatr Res 1986; 23: 337a.

11. McFarland JG. Prenatal and perinatal management of alloimmune cytopenias, in Nance ST (Ed.): Alloimmunity: 1993 and beyond. Bethesda, AABB 1993:165-195.

12. Skogen B, Bellissimo DB, Hessner MJ, Santoso S, Aster RH, Newman PJ, McFarland JG. Rapid determination of platelet alloantigen genotypes by polymerase chain reaction using allele-specific primers. Transfusion 1994; 34: 955-960.

13. Valentin N, Vergracht A, Bignon JD, et al. HLA-DRw52a is involved in alloimmunization against $\mathrm{Pl}^{\mathrm{A} 1}$ antigen. Hum Immunol 1990; 27: 73.

14. Murphy MF, Metcalf $\mathrm{P}$, Waters AH, et al. Antenatal management of severe feto-maternal alloimmune thrombocytopenia: HLA incompatibility may affect responses to fetal platelet transfusions. Blood 1993; 81: 2174-2179.

15. Nordhagen R, Lilleaas E. Neonatal alloimmun trombocytopeni. Serologiske undersøkelser. Tidsskr Nor Loegeforen 1991; 111: 1233-1235.

16. Husebekk A, Skogen B, Christiansen D, Ellingsen L. Neonatal alloimmun trombocytopeni. Diagnostikk, og oppfølging i svangerskapet. Tidsskr Nor Laegeforen 1996; 116: 1219-1222.

17. Bussel J, Berkowitz R, McFarland JG, et al. Antenatal treatment of neonatal alloimmune thrombocytopenia. $N$ Engl J Med 1988; 319: 1374-1378.

18. Daffos F, Forestier F, Muller JY, et al. In utero platelet transfusion in alloimmune thrombocytopenia. Lancet 1984; 2: 1103-1104.

19. Skogen B, Christiansen D, Husebekk A. Flow cytometric analysis in platelet crossmatching using a platelet suspension immunofluorescence test. Transfusion 1995; 35: 832-836.

20. Kiefel V, Santoso S, Weisheit M, Mueller-Eckhardt C. Monoclonal antibody-specific immobilization of platelet antigens (MAIPA): a new tool for identification of platelet-reactive antibodies. Blood 1987; 70: 1722-1726. 